Portland State University

PDXScholar

$1-2018$

\title{
Naming Brazil's Previously Poor: "New Middle Class" as an Economic, Political, and Experiential Category
}

Charles H. Klein

Portland State University, chklein@pdx.edu

Sean T. Mitchell

Rutgers University - Newark

Benjamin Junge

SUNY New Paltz

Follow this and additional works at: https://pdxscholar.library.pdx.edu/anth_fac

Part of the Social and Cultural Anthropology Commons

Let us know how access to this document benefits you.

\section{Citation Details}

Klein, Charles H.; Mitchell, Sean T.; and Junge, Benjamin, "Naming Brazil's Previously Poor: "New Middle Class" as an Economic, Political, and Experiential Category" (2018). Anthropology Faculty Publications and Presentations. 137.

https://pdxscholar.library.pdx.edu/anth_fac/137

This Post-Print is brought to you for free and open access. It has been accepted for inclusion in Anthropology Faculty Publications and Presentations by an authorized administrator of PDXScholar. Please contact us if we can make this document more accessible: pdxscholar@pdx.edu. 


\title{
NAMING BRAZIL'S PREVIOUSLY POOR: 'NEW MIDDLE CLASS' AS AN ECONOMIC, POLITICAL, AND EXPERIENTIAL CATEGORY
}

\begin{abstract}
The early years of the 21 st century were historic for socioeconomic relations in Brazil. While long known for stark socioeconomic inequality, the nation became internationally celebrated for its economic growth and successful poverty-reduction initiatives, which together propelled some 35 million "previously poor" Brazilians into what became called a "new middle class." The apparent rise of this "new" class has generated contentious debates and a range of social science studies in Brazil; yet this literature is little known in the Anglophone academic world. While some have interpreted this demographic transformation as an expansion of the existing middle class, others have questioned the utility of income- or consumption-based criteria for the category middle class. Drawing from ongoing research in working-class neighborhoods in three Brazilian cities (Recife, Rio de Janeiro, and São Paulo), this article reviews and engages these important debates, examines the extent to which Brazil's class structure has changed, and presents a conceptual framework for understanding experiences of socioeconomic mobility and class subjectivities among Brazil's "previously poor."
\end{abstract}

The middle class is necessarily an ill-defined entity. This does not reflect a lack of theoretical penetration but rather the character of reality (Wacquant 1991, 57).

\section{Brazilian Inequality and the "New Middle Class"}

In 2008, as Brazilians were becoming aware of their country's rising international profile and decreasing poverty, economist Marcelo Neri announced the arrival of a "new middle class," with millions of once-poor people joining its ranks each year. Neri argued that with these shifts, Brazil had become a middle-class nation (2008). Brazil is, of course, renowned for brutal inequality — so much so that "Brazilification" is often used as a shorthand for widening inequality elsewhere. So, the idea of a middle-class nation arrived as both revelation and controversy. Politicians and marketers took up the catchphrase, "new middle class," even as critics assailed its validity. This debate continues today, even in the changed context of a severe economic downturn that began in 2013, the impeachment of Workers' Party (PT) President Dilma Rousseff in 2016, and the subsequent rollback of many of the PT social policies that 
supported poverty reduction during the party's years in office (2003-2016). The current crisis stands in contrast to the optimistic years preceding, when Brazil's economic rise and the "new middle class" dominated headlines. Our historical distance from those brighter times give us, perhaps, enough remove to consider the implications of Brazilian debates on the "new middle class" and to evaluate their significance for anthropological theory and ethnography.

We begin below with an account of the profound socioeconomic transformations that took place in Brazil during the first decade of the $21^{\text {st }}$ century. We then review how Marx, Weber and Bourdieu have influenced the study of class by social scientists in Brazil. We next analyze the history and debates surrounding the popularization of the category "new middle class" and review recent ethnographic studies of economically ascendant Brazilians. In conclusion, we offer some suggestions on how ethnographic approaches can contribute to understanding the contradiction-laden terrain of class stratification and subjectivity.

Throughout, we present preliminary findings from our in-progress, three-year anthropological study of social, economic, and geographic mobility among the so-called "new middle class" in Recife, Rio de Janeiro, and São Paulo. In each city, we identified neighborhoods $\operatorname{areas}^{1}$ where 2010 mean per-capita household income fell within the range generally associated with the Brazilian census categories "upper poor" and the "lower middle class"-locations in which we would today expect to find high numbers of adult Brazilians who experienced upward socioeconomic mobility during this period of poverty reduction and rising wages. In twelve of these areas (four per city), we conducted a structured household survey in mid-2016 focused on socioeconomic mobility and subjectivities, and continue with community ethnography using a

\footnotetext{
${ }^{1}$ Most of these areas were confined to single neighborhoods. But in a few cases, the areas were made up of geographically and socially contiguous areas that spanned more than one official neighborhood. For example, Bangú, Padre Miguel, and Realengo are three contiguous Rio de Janeiro west zone neighborhoods that comprised a single sampling area.
} 
range of qualitative methods. Our project places particular attention on the extent to which shifting patterns of consumption, work, and distinction among the previously poor $^{2}$ may destabilize common class categories and reshape political subjectivities and forms of political action. Moreover, our discussion here does not intend to stabilize the inherently fuzzy category "middle class." Rather, by elucidating how the category "new middle class" has been used and contested, we hope to shed light on a period of significant social and economic change in Brazil. In doing so, we aim to sketch an analytic framework for anthropological research on the lived experiences of the millions of Brazilians classified as "poor" in 2000 and then "middle class" just over a decade later, a model that may also prove useful for other societies.

\section{Economic Transformations}

During the two-term, 2003-2010 presidency of Luiz Inácio Lula da Silva (popularly known as “Lula”), Brazil's GNP saw steady growth as millions of poor Brazilians experienced unprecedented upward economic mobility (Pochmann 2012; Loureiro 2012; de Souza 2012). Neri estimated that poverty fell by more than $55 \%$ during the Lula years, with nearly nine million households (more than 30 million people) rising out of poverty (Kerstenetzky et al. 2015) and poverty reductions continued in the first term (2010-2014) of Lula's PT successor, Dilma Rousseff. Neri also reported significant decreases in inequality during this period, as the percapita income of the poorest $10 \%$ of households increased by $80.8 \%$ while the income of wealthiest $10 \%$ of households increased by only $26.9 \%(2014,109)$. Some economists have argued that Neri's methodology overestimates the reduction of economic inequality (Medeiros, Souza, and Castro 2015), but significant poverty reduction during this period is not disputed.

\footnotetext{
${ }^{2}$ Because the term "new middle class" is so contentious and analytically fuzzy, we use "previously poor" as our own term to describe the 35-40 million Brazilians that rose above Brazil's official poverty line in the early $21^{\text {st }}$ century.
} 
Economists have explained these poverty reductions as the combined result of commodity and consumer-debt driven economic growth, labor market expansion, new socialwelfare and education programs, ${ }^{3}$ and increased minimum wages. ${ }^{4}$ During the first 12 years of PT governance, the overall unemployment rate decreased from $13.0 \%$ to $5.0 \%$; informal employment decreased $22.5 \%$ to $13 \%$; and unemployment insurance coverage increased by $99 \%$ (Weisbrot, Johnston, and Lefebvre 2014). Growth in formal-sector employment allowed millions of Brazilian workers to receive mandated labor-law protections and benefits for the first time (e.g., pensions, paid sick leave, disability benefits, and regulated work hours and conditions). Additionally, through various educational reforms, average school years completed rose from 4.98 in 1992 to 7.46 in 2011 and the number of enrolled university students increased from 3.04 million to 7.04 million (Weisbrot, Johnston, and Lefebvre 2014).

While lower-income Brazilians experienced significant increases in household income and consumption from 2003 to 2014, the question remains as to whether these changes signaled a concomitant reorganization of class structure, class relations, and class-linked subjectivity. To examine these possible structural transformations, in June-August 2016, we conducted a survey of 1,200 households in Recife, Rio de Janeiro, and São Paulo. We selected 12 neighborhood areas (four in each city) based on an analysis 2010 Brazilian census data that identified tracts where we would expect to find high numbers of previously poor. For each area, we used cluster sampling to select ten census tracts that met our inclusion criteria, and then conducted ten

\footnotetext{
${ }^{3}$ The most well-known PT social-welfare program is the Bolsa Família (Family Allowance) conditional cash transfer program, which provides a small payment to extremely poor families on the condition that they have their children vaccinated and enrolled in school (World Bank 2013; Glewwe and Kassouf 2012; Kerstenetzky 2008).

${ }^{4}$ Between 2003 and 2014, Brazil's minimum salary grew 76\% after adjusting for inflation, while expanded social security benefits provided 18.3\% of all income in Brazil (Weisbrot, Johnston, and Lefebvre 2014). In Brazil, retirement and other benefits, as well as many higher salaries, are pegged to the minimum salary. So an increase in the minimum salary has expansionary effects well beyond those stemming from the minimum salary itself.
} 
interviews in each tract. ${ }^{5}$ Paralleling the national trends discussed above, preliminary results from our survey indicate sizeable numbers of households reporting improved financial situation (38.7\%) and quality of life (44.9\%) from 2003 to 2011. Far fewer (16.7\%), however, believed that they had achieved an improvement in their relative position on the socioeconomic pyramid.

\section{What is a Middle Class?}

Before considering the contentious discussions in Brazilian academic circles and policy arenas, we provide a sketch of some theoretical perspectives that have shaped Brazilian debates. Most neoclassical economists measure class - including the middle class — using quantitative metrics, as Neri did when he coined the term "new middle class" (2008). Economic definitions of middle class commonly include measures of consumption (Hassett and Mathur 2012); income (D'Agostino 2012; Elwell 2014); wealth holdings (Piketty 2014); and/or the ratio of household disposable income to median income in a particular population (Pressman 2015). Calculations of this sort have been foundational for many analysts who have defended Neri's thesis. However, as our preliminary findings suggest, noting material gains is not sufficient to explain whether and how class relations and class subjectivity have shifted. Seeking to better understand these processes, Brazilian critics of Neri-and some of his defenders- have relied on perspectives outside of neoclassical economics, in particular, those of Marx, Weber, and Bourdieu.

For Marx, classes emerge out of structural relations between groups involved in productive relations. In capitalist societies, the bourgeoisie own the means of production and purchase at exploitative rates the labor time of the proletariat to extract surplus value (profits).

\footnotetext{
${ }^{5}$ In Recife and São Paulo we used a systematic sampling methodology in which we randomly selected streets within these census tracts and then approached every fifth house for study participants. Due to safety concerns in Rio de Janeiro neighborhoods undergoing armed conflict in the wake of the breakdown of Rio's system of Police Pacifying Units (Arias and Barnes 2017), it was not possible to carry out this randomized procedure. In Rio, the research team relied heavily on local informants to minimize danger and to achieve a representative sample of households distributed on streets of the census districts.
} 
There would not seem much room in such a dichotomized schema for a "middle class," but the term appears frequently in Marx's writing. In The Communist Manifesto, Marx predicts the disappearance of much of the middle class in a brutally transforming bourgeoisie order (2012, 44), and some interpreters of Marx have treated the middle class/petit bourgeoisie category as a kind of false consciousness (e.g., Klingender 1935). But in his later work, Marx notes the "continual increase in numbers of the middle classes, of those who are situated midway between the workers on one side and the capitalists and the landowners on the other" (Marx 1999; cited in Wacquant 1991, 40-41; see also, Urry 1973). With the rise of dominant, middle-class societies in the Euro-Atlantic world in the years after World War II, Marxist analysts have continued to develop more complex conceptualizations of the "middle" class, including Barbara and John Ehrenreich, who influentially designated the "professional-managerial class" as the distinct class of educated laborers who work towards the "reproduction of capitalist culture and capitalist class relations" $(1979,12)$.

Marxist perspectives have been influential in Brazilian debates, particularly among critics who question the category's validity. For example, André Singer, a well-known political scientist who was press secretary in PT president Lula's first term, argued that because about half of the Brazilian population is a sub-proletariat living on the margins of the formal economy, "the proletariat, properly speaking, occupies an intermediate position in Brazil, which can lead to the mistaken perception that they are a middle class" (Singer 2015, 9). ${ }^{6}$ Most Brazilian Marxist analyses of the "new middle class" similarly position the recently economically ascendant within the proletariat (Kerstenetzky et al. 2015; Pochmann 2014; R. Braga 2015). However, whether

\footnotetext{
${ }^{6}$ This and all other translations from the Portuguese are our own.
} 
and how Brazil's early $21^{\text {st }}$ century previously poor might constitute a new and distinct stratum, with shared consciousness of interests, has been little explored.

This question of class consciousness-whether the previously poor are becoming a class "for itself" - is central to Marxist analyses of the Brazilian "new middle class," and some critics have suggested that Brazil's poor and previously poor in the PT era were duped into interests not their own (Anderson 2011). Our data are still too preliminary to definitively answer this question of class consciousness among Brazil's previously poor. Our research does, however, suggest that the ascendant are not some kind of "managerial-professional" buffer between labor and capital. For example, in São Paulo, the center of Brazil's dynamic financial and technology sectors, only $4.6 \%$ of respondents reporting holding managerial or professional positions, and half of these were teachers. ${ }^{7}$ The most commonly reported occupations were non-supervisorial office work (15.9\%), skilled manual labor (14.8\%), unskilled manual labor (14.0\%), and self-employed small businesspeople $(13.5 \%)$, with another $12.7 \%$ reporting having no occupation. ${ }^{8}$

That social hierarchies are shaped by both economic and non-economic structures is, of course, central to the work of Max Weber. For Weber, there are multiple axes of power in capitalist societies, with people differentiated by degrees and types of honor (status) and political affiliations (party), beyond ownership of economic capital (1978). Combining economistic and Weberian perspectives, sociologist Amaury de Souza and political scientist Bolívar Lamounier (2010) affirm the existence of Neri's new middle class, but highlight the persistent status distance between new and traditional middle classes (2010) ${ }^{9}$. For these authors, "new" middle

\footnotetext{
${ }^{7}$ Other professional occupations in the São Paulo sample include general manager, financial director, financial analyst, network analyst, programmer, pharmacist, and physical therapist.

${ }^{8}$ In addition to these reported occupations, $6.0 \%$ of the São Paulo sample reported their occupation as unemployed, $4.6 \%$ as retired, $4.6 \%$ as housewives, and $1.9 \%$ as student.

${ }^{9}$ When we refer to the "traditional middle class," we use the term colloquially to refer to the mostly professionalclass or inherited-money elite in Brazil that many contemporary economists position in the upper C and B class, and urban Brazilians frequently refer to as "middle class." Although the C class concentrates around a statistical median,
} 
classes seek to emulate more elite traditional middle classes, but have low social capital, rely on credit for consumption and worry little about democratic institutions (2010). Their conclusions echo a longstanding characterization of middle classes as seeking status and to emulate higher classes (Fussell 1992; Mills 2002). This apparent chasm between traditional and new middleclass individuals is supported by our survey data, as respondents agreed that "the rich think they are better than the poor" $(\mathrm{M}=4.13$ on a 1 -to-5 Likert scale in which $1=$ strongly disagree and $5=$ strongly agree) and "rich people are bothered by the rise of the poor" $(M=3.67)$. However, our preliminary data do not support the emulating-higher-classes hypothesis. For example, $24.7 \%$ of our sample chose funk, which is generally associated with the urban poor, as their preferred style of music — by far the most popular style in our survey—while no respondents chose MPB (Música Popular Brasileira), the style of music most associated with Brazil's educated urban middle class. ${ }^{10}$

Seeking to understand how such inter-class distinctions between the new and traditional middle classes distinctions are maintained and subverted, many Brazilian scholars have applied Bourdieu's concepts of cultural capital $(1984,228)$ and habitus, the embodiment of cultural capital as a series of class-inflected dispositions. For example, anthropologists Hilaine Yaccoub (2011) and Eliana Vicente (2013) have used Bourdieu to ethnographically examine how taste and consumption shape the lives and class position of the previously poor in Rio de Janeiro, while sociologist Jessé de Souza utilizes Bourdieu to critique the economistic character of the new middle-class thesis (2013). Our own data affirm the importance of consumption as a marker

the expansion of which was central to Neri's thesis, in urban Brazil, the term "middle class" does not colloquially encompass the entire statistical C class category.

${ }^{10}$ Funk is a style of dance music developed in Rio de Janeiro's favelas in the 1980s, quite distinct from the funk that was developed in the 1960s in the United States. Although increasingly popular throughout Brazil, it is often associated with the urban poor. MPB is a style of music developed in the 1960s and 1970s, drawing on Brazilian styles such as Bossa Nova and Samba and foreign styles, such as jazz and rock. 
of ascension. Many households, for example, have items once the near-exclusive provenance of traditional middle-class families, such as cell phones (75\%), expensive fixed telephone lines (46\%), Internet access (68\%), computers (55\%), cars (37\%), and freezers (34\%). Thirty percent of the households had someone who travelled domestically by plane since 2013 , and $7 \%$ in which someone travelled internationally. How these consumption practices shape class subjectivities - including in the highly-charged terrain of interactions with traditional middleclass Brazilians_-are key themes in our current qualitative research.

\section{The Neri Debates}

We now consider the debate on the "new middle class" that followed Neri's 2008 pronouncement. Neri's argument builds on a descending five-letter, A-to-E class taxonomy (with A the richest, and $\mathrm{E}$ the poorest) commonly used by Brazilian demographers, economists, and market researchers. This letter-based class categorization has two forms - one based on household income (calculated as the number of monthly minimum salaries earned) and widely used to analyze data collected by the Brazilian Institute of Geography and Statistics (IBGE), and a second, the Critério Brasil ${ }^{11}$ emphasizing consumption over income and commonly used by market researchers.

In their 2008 publication, Neri and colleagues showed that during the period 2003-2008, approximately 30 million Brazilians rose into the $\mathrm{C}$ class (defined then as having monthly household income between R \$ 1126-4854 or USD\$ 470-2022). ${ }^{12}$ With this influx, the C class increased to approximately 95 million Brazilians, representing more than half (approximately

\footnotetext{
${ }^{11}$ The Critério Brazil system, developed by the Brazilian Association of Research Firms (ABEP), uses a point system based on the household presence of consumer items, domestic workers, and education levels.

12 These parameters and exchange rate represent 2009 values.
} 
$50.5 \%$ ) of the population, and Neri proposed that Brazil had become a middle-class nation. While initially underscoring the statistical character of the "new middle class" $-\mathrm{C}$ is the statistical middle of an A to E scale - Neri's subsequent reports $(2010 ; 2012)$ increasingly treated this group as having internal coherence and shared meaning for its members, reflected, for example, in his public statements that the "new middle class...[could] decide an election campaign" (2010).

The proclaimed ascendance of the "new middle class" catapulted Neri into the national spotlight and elicited celebration among PT-allied politicians, as well as marketers, and businesses who perceived, alternately, a vindication of PT social policies and a massive, emerging electoral and consumer force. Indeed, the "new middle class" rapidly emerged as a key symbol of a "New Brazil" (Kopper 2016) - a post-authoritarian, post-neoliberal "country of the future" that had finally found its present. Near this enthusiasm's crest, in 2011, the federal government established a commission to reflect on the hopes, dreams, and prospects of this population. Popularly known as the "Voices of the Middle Class" project, the commission created a website and several publications to give a public face to the supposed new class.

Yet Neri's thesis has faced many challenges. Several Weberian-influenced studies have argued that income-based definitions oversimplify class experience and have, instead, emphasized occupation and market insertion, factors that receive only secondary attention in Neri's analyses (Pochmann 2012; Salata and Scalon 2015; Sobrinho 2011). These analysts further stress how Neri's framework obscures - and depoliticizes — longstanding categories such as "working class" and the colloquial, "classe popular." A second line of critique builds on Bourdieu and argues that the supposed new middle class has neither the habitus of the traditional middle class nor its cultural capital (J. de Souza 2010; Yaccoub 2011). A third line of critique 
has highlighted how Neri's economic definition of the "new middle class" masks the fact that increases in income and consumption have not translated into a reduction of structural inequality and cannot therefore be said to have ushered in a new class order (Vicente 2012; Esteves 2015; Sobrinho and De 2014). Or, even if a new class has been created, it may be a new working class resulting from the expansion of the proletarian base whose household living conditions may be closer to "poor" than to "middle class" (Pochmann 2012; A. de Souza and Lamounier 2010; Sobrinho 2011; Singer 2015). In response to these debates, the federal government in 2014 went so far to establish a Commission for the Definition of the Middle Class in Brazil (Sathler 2014).

Our household data offer support for all three critiques of the new-middle-class hypothesis discussed above and suggest that the previously poor might best categorized as "working class" or "new C Class," the latter a characterization we regularly hear residents of our study communities invoke. As Table 1 below highlights, socioeconomic mobility notwithstanding, only $4.7 \%$ self-identify as "new middle class." Most common identifications were with "working class (41.9\%), "C class" (41.2\%), and "D class" (29.7\%). Few respondents (9.6\%) place themselves within the "B class," the categorical home of the upper reaches of Brazil's traditional middle class. These preliminary findings suggest that class-linked subjectivities are highly plural among Brazil's "previously poor"-a heterogeneous group who see themselves as middle class, lower middle class, new middle class, working class, and/or lower class.

Table 1. Self-Ascribed Class Labels

\begin{tabular}{|lr|r|r|}
\hline Class Label Identification & & Total & $\%$ \\
\hline Middle class & No & 1028 & 85.4 \\
& Yes & 176 & 14.6 \\
\hline Lower middle class & No & 960 & 79.7 \\
& Yes & 244 & 21.3 \\
\hline New middle class & No & 1148 & 95.3 \\
& Yes & 56 & 4.7 \\
\hline
\end{tabular}




\begin{tabular}{|lr|r|r|}
\hline Working class & No & 700 & 58.1 \\
& Yes & 504 & 41.9 \\
\hline Lower class & No & 904 & 75.1 \\
& Yes & 300 & 24.9 \\
\hline Poor & No & 995 & 82.6 \\
& Yes & 209 & 17.4 \\
\hline A-E Scale & & & \\
\hline A class & No & 1172 & 97.3 \\
& Yes & 32 & 2.7 \\
\hline B class & No & 1089 & 90.4 \\
& Yes & 115 & 9.6 \\
\hline C class & No & 708 & 58.8 \\
& Yes & 496 & 41.2 \\
\hline D class & No & 846 & 70.3 \\
& Yes & 358 & 29.7 \\
\hline E class & No & 1001 & 83.1 \\
& Yes & 203 & 16.9 \\
\hline
\end{tabular}

\section{Qualitative Research}

The nature of the "new middle class" and of possible changes to class relations and subjectivity calls for ethnographic examination-even amid the current economic crisis that has reversed gains for many of the previously poor. We, along with many Brazilian scholars, have begun to investigate the importance of sociocultural factors in shaping class in this context, including, but not limited to, gender, race/color/ethnicity, religion, neighborhood and regional identity, leisure activities, food consumption, and mobility within historically class-segregated urban spaces. In our sample, $71.5 \%$ of respondents categorized themselves as black (preto/a) or brown (pardo/a), compared to only 50.7\% in Brazil's 2010 census. ${ }^{13}$ Given the close-and rapidly changing - links between color and class in Brazil, we suspect that people's experience of racism, race, and color are highly significant in the formation of class subjectivity among the previously poor. We are exploring these interconnections in our qualitative research. Class experiences are further shaped by the spatial and political contexts in which individuals live. In

${ }^{13}$ The 2010 census used 5 census categories: branco/a (white), 47.73\%; pardo/a (brown), 43.13\%; preto/a (black), 7.61\%; amarelo/a (Asian), 1.09\%; indígena (indigenous), $0.43 \%$. 
our household survey sample, Rio de Janeiro respondents either live in favelas, where residents face a lack of public services, significant discrimination outside the neighborhood, and violent conflicts between drug gangs, paramilitary groups, and the police, or in the city's vast north and west zone, where they additionally face brutally long commutes to work in the city's center and affluent south zone. In São Paulo, our sample comes from periphery neighborhoods in the city's sprawling southern zone. Like the Rio de Janeiro respondents, the São Paulo sample faces difficult commutes, but have relatively high infrastructure levels in their largely self-built but now solidified neighborhoods (see Holston 2008). Violence is also high, with police killings of Afro-Brazilian youth common, but these neighborhoods do not currently possess the systematized conflict of Rio de Janeiro. In Recife, one of four survey districts sits behind an affluent beach-front neighborhood fairly close to the downtown Centro, with the previously poor concentrated in apartment complexes (many obtained through the PT-era federal Minha Casa, Minha Vida program) and favelas next to a large mall. Another district is nearly an hour's bus ride from the Centro, with a combination of conventional houses and favelas; and the remaining two districts are about a half-hour from downtown, each characterized by conventional houses. Across the three cities, $52.9 \%$ of respondents reported that they would leave their neighborhood if they could, and people's experiences of ascension, solidarity, and constraint are shaped by these urban geographies in ways we are currently examining through ongoing qualitative research and analysis of our household survey data.

In recent years, Brazilian social scientists have conducted several ethnographic studies on these lived experiences and subjectivities. In these politically and theoretically diverse works, four interconnected themes emerge: 1) the importance of consumption in asserting social and class distinction; 2) the relational nature of class positions and subjectivities, including the role 
of habitus and cultural capital in (re)producing hierarchies; 3) heterogeneity among economically ascendant individuals; and 4) the extent to which many previously poor individuals rely on an individualized, neoliberal meritocratic discursive framework—rather than social and political frameworks_-for explaining socioeconomic mobility.

Reflecting the strong influence of Bourdieu among Brazilian anthropologists, many scholars highlight the importance of consumption as a marker of socioeconomic ascension (Chiosini et al. 2015; A. R. C. Rocha and Rocha 2015; Vicente 2012; Yaccoub 2011). In Rio de Janeiro, anthropologists Yaccoub (2011) and Vicente (2012) both show how consumer items, including remodeled kitchens with stainless steel appliances, serve as a means of asserting status. The display of socioeconomic ascension through consumption is perhaps most dramatically demonstrated when emergent consumers purchase goods and services once limited to traditional middle-class and elite consumers, such as whiskey (Braga 2015), expensive clothing and accessory brands (Scalco and Pinheiro-Machado, 2010), cars (Braga 2015; Rodrigues and Casotti 2015), airplane travel (Chiosini et al. 2015), and cruises (Rocha and Rocha 2015). In these studies, members of a new consumer class present the consumption of such (previously) high-status items as markers of their new position and inclusion in Brazilian society, a transformation captured in the title of Braga's (2015) dissertation, "I was ugly, but now I have a car.” In our survey results, the strongest correlate of reported upward economic mobility since 2003 was the presence of a freezer in the household, another consumption item previously largely limited to traditional middle-class households. Consumption is clearly a key aspect of how people understand and assert their class position.

Several studies highlight the polysemic symbolic processes involved in social consumption mitigating against assertions of a changed class structure (R. da S. Braga 2015; A. 
R. C. Rocha and Rocha 2015; Scalco and Pinheiro-Machado 2010). For example, Braga's (2015) ethnographic study of traditional and new-middle-class youth who frequent forró electrônico ${ }^{14}$ clubs in Fortaleza analyses how owning a foreign car and publicly drinking whiskey and vodka are markers of elevated class status. Braga contrasts how new middle-class and traditional middle-class individuals use these same symbols differently - even as new middle-class individuals consume high-status items to project modernity and sophistication, their ostentatious consumption demonstrates, for many in the traditional middle class, that they do not possess the a traditional middle-class "refined" habitus. And with cost no longer controlling entry to dance halls, club organizers in Fortaleza instituted an "invitation only" policy to maintain traditional middle-class homogeneity (Braga 2015). This pattern of binary habitus differentiation between traditional and new middle-class/lower-income individuals with similar consumption is strikingly present in Rocha et al.'s ethnographic study of middle-class cruise-goers (2015). Here, traditional middle-class passengers describe "new-middle-class" patrons as having bad taste in clothing, acting out of place, and speaking in non-standard diction. At the same time, new middle-class cruise-goers classify, in positive terms, the traditional middle class as having exactly the opposite traits (Rocha et al., 2015; see also Caldeira, 2000; O'Dougherty 2002 on the habitus of the São Paulo traditional middle class). And, for high-end fashion items subject to falsification and pirating, Scalco and Pinheiro-Machado (2010) observe how the traditional middle class may deny that a lower-income individual is using high-end clothing or accessory brands - even when they are - thus denying assertions of ascension.

These uncertain and contradictory classification processes also shape interactions and relationships between the "new middle class" and those who remain poor. On the one hand,

\footnotetext{
${ }^{14}$ Forró is a highly popular style of dance music from the Brazilian northeast, traditionally played with an accordion and varied percussion, but now with many electronic variants.
} 
many economically ascendant individuals still living in their neighborhoods of origin contrast their realities to prototypic middle-class communities and lifestyles. As Yaccoub (2011) describes

not feeling valorized in their jobs and living in 'poor conditions', with few transportation options, precarious public lighting, unpaved roads, and poor quality hospitals, restaurants - not to mention the question of violence-[one informant asked me] 'this is being middle class?'

On the other hand, many economically ascendant individuals distinguish themselves from the poor through higher consumption levels (Scalco and Pinheiro-Machado 2010), relatively safer neighborhoods (Oliveira 2013), and adaptation of lifestyles crafted against dominant practices in their communities - e.g., landscaping yards, and not hanging clothes outside to dry or listening to funk music (Vicente 2013, 118). Our data demonstrate similar dynamics. For example, one of the authors talked to a fitness instructor from Rio de Janeiro's working-class north zone who works giving fitness classes in gyms across the city. In spinning classes she likes to play funk, but in well-to-do the neighborhoods she chooses other genres because many of her customers object to funk, underscoring the importance of forms of class-linked consumption in asserting class position

Ethnographers have also highlighted how the previously poor may rely on a meritocracy discourse that explains socioeconomic ascension as the payoff for hard work (Oliveira 2013; Rodrigues and Casotti 2015; Scalco and Pinheiro-Machado 2010; Vicente 2012; Yaccoub 2011). A centerpiece of this meritocratic worldview is a commitment to education, even when financial rewards are not forthcoming. For example, in Trindade's (2013) focus groups with recent newmiddle-class university graduates in São Paulo, nearly all participants describe their current jobs as unfulfilling means to meet basic needs, yet still believe education might provide greater financial independence and self-realization. At the community level, Vicente (2013) describes 
how one Rio resident, in response to poor public education and a desire to challenge inequality, opened a successful Montessori-inspired private school in her lower-income neighborhood. Few students ultimately enroll in Brazil's prestigious public university system—-the preferred traditional middle-class path—but many obtain degrees from technical and online courses through private institutions. As with Trindade's recent university graduates, Vicente reports that these degrees typically provide few financial rewards.

We have observed similar patterns in our quantitative data — very few of the collegeeducated respondents in our sample (5.2\% have college degrees and 6\% completed some college) report professional-level jobs or salaries, and we rarely encounter public university attendees in our study communities. Nonetheless, our data suggest the "previously poor" do not share a unified framework to explain their socioeconomic ascension and class position. For example, on a 1 to 5 Likert scale, respondents were close to neutral (3.0) on the statements "If you work a lot, you will be successful" (M=3.14), "The most important thing to be successful is to know well-placed people" ( $\mathrm{M}=3.28)$, and "To be successful, it is fundamental to be born into a rich family $(M=2.91)$. Only the statement "To be successful, it is fundamental to have faith in God" received a notably high level of agreement (4.0). Yet, in everyday conversations in our study neighborhoods, few speak of broader socioeconomic and political conditions to explain individual economic position or mobility. Further, respondents were close to neutral on whether they think their socioeconomic mobility is linked to PT policies, as evidenced by a 3.24 average on "The PT improved the lives of people like me" and only a 2.66 average on the statement "You feel represented by the Dilma government." 
Our anecdotal conversations demonstrate that most of our college educated respondents are aware that education has not won them middle class cultural or economic capital. ${ }^{15}$ Nonetheless, for these first-generation college students, a degree marks not only social ascension (Vicente, 2013; see also Oliveira, 2013), but also plays a critical role in shaping life aspirations, identities, and habitus. Unlike their parents, many of whom migrated to the city in search of a better life and worked extremely hard in manual labor jobs to construct their lives - and indeed, their actual houses and neighborhoods - these younger adults grew up in the cosmopolitan atmosphere of large cities in a time of dramatic socioeconomic change. Most say that they will not work as domestics, bricklayers, hair stylists, and bricklayers. In the words of one São Paulo respondent "I would rather be poor than do that kind of work." At the same time, many of the younger, college educated respondents in our study neighborhoods stay in their communities upon completion of their degrees, often working as teachers or social service providers. How education and the dissemination of cultural capital in everyday life shape aspirations, economicdecision-making and urban periphery space are themes we will explore more deeply in our qualitative research.

\section{Inequality, Subjectivity, and Ethnographic Research}

As this paper's epigraph suggests, the category "middle class" is inherently imprecise. Debates over whether Brazil's early 21st century economically ascendant were a "middle class" will not find resolution soon, due to the current economic crisis and austerity policies effectively halting or reversing socioeconomic ascension, the flexibility of the category, and the as yet unknown future that will shape how we see the past. However, these Brazilian debates and our

\footnotetext{
${ }^{15}$ A few respondents have read Bourdieu and have used these very terms.
} 
research suggest: (1) that the class position of the previously poor is laden with contradictions and (2) that there were massive changes to the symbolic and material relations structuring this most unequal society at the start of this century. By presenting these disputes and scholarship to an Anglophone readership, we hope to make better known the complexity of shifting relations of inequality in a nation too often glossed by oversimplified tropes such as "Brazilification" or Brazil's rise as one of the emergent BRICS nations. But what these changes might yield for class relations and politics in Brazil, and how new forms of class consciousness may develop, remains to be examined.

Our ethnographic and quantitative research in neighborhoods where one would expect to find sizeable numbers of "previously poor" Brazilians have shown that almost no one speaks of the "new middle class" in 2016 or 2017. Amid economic decline and a conservative political turn, many previously poor are again poor, or afraid of sliding back into poverty. But even as "new middle class" has faded from the Brazilian headlines and from everyday conversation, the last decade marked an unprecedented period of economic and social change. Whatever happens to the previously poor after having tasted something of middle-class life, social relations and class subjectivity in Brazil are unlikely to return to anything like their late- $20^{\text {th }}$-century patterns.

The "new middle class" debate is an artifact of a unique moment in Brazilian history. Yet the significance of changes to Brazil's inequality at the start of the $21^{\text {st }}$ century — and their effects on political and social life — seem to persist. Gilberto Freyre once argued that Brazilian society was characterized by "antagonisms in equilibrium" $(1933,415)$. The ferocity of traditional middle-class backlash (Boito Jr. 2016) in the years following Brazil's upheaval of 2013 (Dent and Pinheiro-Machado 2014) and culminating in the impeachment of PT president, Dilma Rousseff, suggests to us that this equilibrium has weakened, unsettling longstanding patterns of 
class deference. Yet, other than Oliveira's (2013) dissertation on class, ideology, and voting patterns of new-middle-class and lower-income residents in São Paulo, there is surprisingly little ethnographic research on political subjectivities among the "new middle class" and those classes with whom they interact.

A second theme largely absent from the ethnographic literature is the interconnection between race/color/ethnicity and class. Since disproportionate numbers of the economically ascendant are non-white, Nordestino, ${ }^{16}$ or both, and disproportionate numbers of the traditional middle class are white, many of the changing relations of inequality debated in Brazil undoubtedly involve an ethnoracial dimension that await ethnography and analysis. Given that ethnographic literatures on race and class in Brazil are both booming fields of scholarly inquiry, and given the pigmentocratic character of Brazil's economic hierarchies (Telles 2014), it is surprising that the two literatures have so seldom met.

A third unstudied theme that may play a role in emergent class subjectivities is the impact of the Internet and social media. These new forms of communication and connectivity are undoubtedly changing how cultural capital is acquired and made use of in everyday life (see, for example, Raposo's 2015 study of the cosmopolitan breakdancers from the Maré favela in Rio de Janeiro). Such processes are likely transforming existing patterns of social distinction and may reconfigure the poor/popular-class versus middle-class/elite habitus binary that has long dominated scholarly accounts of Brazilian society.

Taken together, this review of extant research and theory—supported by our preliminary findings - point to the need for a highly flexible conceptual framework to understand

\footnotetext{
${ }^{16}$ Nordestinos are individuals from Brazil's northeastern region, the poorest region in the country. During the middle half of the 20th century, tens of millions of migrated from the poorer northeast to richer southeastern cities, to enter the ranks of the poor and working class, and to be subject to stereotyping and discrimination.
} 
experiences of mobility subjectivity among Brazil's previously poor. In conclusion, we offer several starting points for addressing the complexities of research on urban populations undergoing rapid periods of socioeconomic mobility.

1. The habitus of economically ascendant populations is not merely an emulation of that of existing middle classes in some "trickle-down" rendition of Bourdieu's practice theory. The desire for an iPhone, a flat-screen TV, or a car has more to it than mimesis of an idealized elite- even when discourses of class emulation are prevalent, as they are in Brazilian cities.

2. Class is shaped within "shifting fields of gender, race, ethnicity, and geography" (Heiman et al. 2012, 14). In a Brazil characterized by race and gender relations forged in slavery and its long dissolution, class should be analyzed in relation to race and gender. Relatedly, the experience of urban geography is fundamental in the experience of class mobility, including spatial segregation (Caldeira 2002; Heiman 2012; Srivastava 2012), transportation infrastructure, and the connection of class subjectivity to the construction and contestation of public space.

3. Class position is not simply an "identity," but also a material and structural relation. Despite the importance of identity categories in understanding class, theories of class should not simply be assimilated to theories of identity. Research on the previously poor should include analysis of valued material and symbolic goods as well as tensions and changing relationships in places of work, consumption, and sociality, including interactions with the elite, traditional middle class and the poor who have not experienced economic ascension.

4. Class mobility is interconnected with people's life projects, political desires, personal aspirations, regrets and nostalgia over time. How people conceive of the past, present, and 
future - and how they imagine the desirable and the possible — are fundamental to understanding economic mobility.

Thomas Piketty has recently marshaled extensive historical evidence to show that over the long-term middle classes do not fare well in most capitalist economies (2014). Yet, over the last decade, even as the middle classes of the Global North have shrunk, some nations in the Global South (Brazil, China, and India, in particular) underwent unprecedented economic growth and poverty reduction (Lakner and Milanovic 2015). This period has may have ended — at least in Brazil-but it is only through detailed ethnographic research that we can uncover what these rare changes in so unequal a context might mean and bode for the present and future.

\section{Works Cited}

Anderson, Perry. 2011. "Lula's Brazil.” London Review of Books 33 (7): 3-12.

Arias, Enrique Desmond, and Nicholas Barnes. 2017. “Crime and Plural Orders in Rio de Janeiro, Brazil.” Current Sociology 65 (3): 448-65.

Boito Jr., Armando. 2016. Os Atores E O Enredo Da Crise Política. Edited by Ivana Jinkings, Murilo Cleto, and Kim Doria. São Paulo: Boitempo Editorial.

Bourdieu, Pierre. 1984. Distinction: A Social Critique of the Judgement of Taste. Translated by Richard Nice. Cambridge, Mass.: Harvard University Press.

Braga, Robson da Silva. 2015. "Eu era feio, agora tenho carro: Encenações e práticas de consumo em clubes de forró de Fortaleza.” http://www.lume.ufrgs.br/handle/10183/109704.

Braga, Ruy. 2015. A Política Do Precariado: Do Populismo À Hegemonia Lulista. Boitempo Editorial. 
Caldeira, Teresa P.R. 2000. City of Walls: Crime, Segregation, and Citizenship in São Paulo. Berkeley, CA: University of California Press.

Chiosini, Ana Carolina, Catherine Sampaio Maximino, Laís Machado Pereira da Silva, Ligia Melo Borges Milhorati, and Sergio Silva Dantas. 2015. “A experiência do público de baixa renda na compra e consumo de passagens aéreas." Jovens Pesquisadores Mackenzie 11 (1).

http://mackenzie.br/dhtm/seer/index.php/jovenspesquisadores/article/view/1248.

D’Agostino, Brian. 2012. The Middle Class Fights Back: How Progressive Movements Can Restore Democracy in America. Santa Barbara, Calif: Praeger.

Dent, Alexander S., and Rosana Pinheiro-Machado. 2014. "Introduction: The Cellularity and Continuity of Protest in Brazil.” Anthropological Quarterly 87 (3): 883-885.

Ehrenreich, Barbara, and John Ehrenreich. 1979. "The Professional-Managerial Class.” In Between Labor and Capital, edited by Pat Walker, 5-48. Boston: South End Press.

Elwell, Craig K. 2014. "The Distribution of Household Income and the Middle Class." http://digitalcommons.ilr.cornell.edu/key_workplace/1263/.

Esteves, Anderson Alves. 2015. “A Ideologia Da 'classe C' como a Classe Média Brasileira.” Intuitio 8 (1): 15-31.

Freyre, Gilberto. 1933. Casa grande e senzala: formação da família brasileira sob o regime da economia patriarcal. Rio de Janeiro: Maia \& Schmidt.

Fussell, Paul. 1992. Class: A Guide Through the American Status System. Reissue edition. New York: Touchstone. 
Glewwe, Paul, and Ana Lucia Kassouf. 2012. "The Impact of the Bolsa Escola/Familia Conditional Cash Transfer Program on Enrollment, Dropout Rates and Grade Promotion in Brazil.” Journal of Development Economics 97 (2): 505-17.

Hassett, Kevin A., and Aparna Mathur. 2012. "A New Measure of Consumption Inequality." AEI Economic Studies, no. 2. http://papers.ssrn.com/sol3/papers.cfm?abstract id=2212998.

Heiman, Rachel, Carla Freeman, and Mark Liechty. 2012. "Introduction: Charting an Anthropology of the Middle Classes." In The Global Middle Classes: Theorizing Through Ethnography, edited by Rachel Heiman, Carla Freeman, and Mark Liechty, 330. SAR Press.

Holston, James. 2008. Insurgent Citizenship: Disjunctions of Democracy and Modernity in Brazil. Princeton: Princeton University Press.

Kerstenetzky, Celia Lessa. 2008. "Development and Redistribution: The Case of the Bolsa Familia Program in Brazil.” Textos Para Discussão, TD, no. 240.

Kerstenetzky, Celia Lessa, Christiane Uchôa, Nelson do Valle Silva, Celia Lessa Kerstenetzky, Christiane Uchôa, and Nelson do Valle Silva. 2015. "The Elusive New Middle Class in Brazil.” Brazilian Political Science Review 9 (3): 21-41. Klingender, F. D. 1935. The Condition of Clerical Labour in Britain / by F.D. Klingender ; with a Preface by W.J. Brown. Martin Lawrence.

Kopper, Moisés. 2016. “Arquiteturas Da Esperança: Uma Etnografia Da Mobilidade Econômica No Brasil Contemporâneo.” http://www.lume.ufrgs.br/handle/10183/141243.

Lakner, Christoph, and Branko Milanovic. 2015. "Global Income Distribution: From the Fall of the Berlin Wall to the Great Recession." The World Bank Economic Review 30 (2): lhv039. 
Loureiro, Andre OF. 2012. "Can Conditional Cash Transfers Reduce Poverty and Crime?

Evidence from Brazil." Evidence from Brazil (January 30, 2012). http://papers.ssrn.com/sol3/papers.cfm?abstract_id=2139541.

Marques, Eduardo, ed. 2015. A metrópole de São Paulo no século XXI, Espaços, Hetergeneidades e Desigualdades. Editora Unesp/CEM.

Marx, Karl. 1999. Theories of Surplus Value. Prometheus Books.

Marx, Karl, and Friedrich Engels. 2012. The Communist Manifesto: A Modern Edition. Edited by Eric Hobsbawm. Verso Books.

Medeiros, Marcelo, Pedro HGF Souza, and Fabio Avila de Castro. 2015. “O Topo Da Distribuição De Renda No Brasil: Primeiras Estimativas Com Dados Tributários E Comparação Com Pesquisas Domiciliares, 2006-2012 (Top Incomes in Brazil: First Estimates with Tax Data and Comparison with Survey Data, 2006-2012).” DADOSRevista de Ciências Sociais, Rio de Janeiro 58 (1). http://papers.ssrn.com/sol3/Papers.cfm?abstract_id=2479685.

Neri, Marcelo Côrtes. 2008. “A Nova Classe Média.” Rio de Janeiro: FGV/IBRE, CPS.

—. 2010. "Good news for the poor." The Brazilian Economy 2 (10): 24-27.

—. 2012. A Nova Classe Média: O Lado Brilhante Da Base Da Pirâmide. São Paulo: Saraiva.

—. 2014. "Poverty Reduction and Well- Being: Lula's Real." In Brazil Under the Workers' Party, edited by Fábio de Castro, Kees Koonings, and Marianne Wiesebron, 102-25. Palgrave Macmillan UK. http://link.springer.com/chapter/10.1057/9781137273819_6.

O’Dougherty, Maureen. 2002. Consumption Intensified: The Politics of Middle-Class Daily Life in Brazil. Duke University Press. 
Oliveira, Camila Rocha de. 2013. "Encontros E Desencontros Entre Petismo E Lulismo: Classe, Ideologia E Voto Na Periferia de São Paulo.” Universidade de São Paulo.

Piketty, Thomas. 2014. Capital in the Twenty-First Century. Translated by Arthur Goldhammer. Cambridge: Belknap Press.

Pochmann, Márcio. 2012. Nova Classe Média? Boitempo Editorial.

—. 2014. O mito da grande classe média: Capitalismo e estrutura social. São Paulo, SP: Boitempo Editorial.

Pressman, Steven. 2015. "Defining and Measuring the Middle Class." 7. Working Paper. Great Barrington, MA: American Institute for Economic Research. https://www.aier.org/sites/default/files/Files/Documents/Standard/WP007Middle\%20Class.pdf.

Raposo, Otávio. 2015. “'Nós Representa a Favela Mano’. B-Boys Da Maré Superando Estereótipos.” Antropolítica: Revista Contemporânea de Antropologia, no. 37. http://www.revistas.uff.br/index.php/antropolitica/article/viewArticle/252.

Rocha, Ana Raquel Coelho, and Everardo Rocha. 2015. “Classifying and Classified: An Interpretive Study of the Consumption of Cruises by the 'new' Brazilian Middle Class." International Business Review, March.

Rodrigues, Tonny Kerley de Alencar, and Leticia Moreira Casotti. 2015. “Queremos mobilidade! Lógicas de consumo associadas à experiência com o primeiro automóvel." Revista de Administração da Unimep - Unimep Business Journal 13 (1): 220-47.

Salata, André, and Celi Scalon. 2015. “Do Meio À Classe Média: Como a ‘nova Classe Média’ E a 'classe Média Tradicional’ Percebem Sua Posição Social?” Ciências Sociais Unisinos $51(3)$. 
Sathler, Luciando. 2014. "Relatório Definição Da Classe Média No Brasil.” Economy \& Finance. http://www.slideshare.net/lsathler/relatrio-definio-da-classe-mdia-no-brasil.

Scalco, Lucia Mury, and Rosana Pinheiro-Machado. 2010. “Os Sentidos Do Real E Do Falso: O Consumo Popular Em Perspectiva Etnográfica.” Revista de Antropologia, 321-359.

Singer, André. 2015. "Quatro Notas Sobre as Classes Sociais Nos Dez Anos Do Lulismo." Psicologia USP 26 (1): 7-14.

Srivastava, Sanjay. 2012. "National Identity, Bedrooms, and Kitchens: Gated Communities and New Narratives of Space in India." In The Global Middle Classes: Theorizing Through Ethnography, edited by Rachel Heiman, Carla Freeman, and Mark Liechty, 57-84. SAR Press.

Sobrinho, Figueiredo, and Carlos Peres De. 2014. "Jornalismo de serviço: Política, discurso, representação e participação em disputa." http://repositorio.ufpe.br:8080/xmlui/handle/123456789/11719.

Sobrinho, Guilherme G. de F. Xavier. 2011. “A ‘Classe C’ E Sua Alardeada Ascensão: Nova? Classe? Média?" Indicadores Econômicos FEE 38 (4).

Souza, Amaury de, and Bolivar Lamounier. 2010. A Classe Média Brasileira: Ambições, Valores E Projetos de Sociedade. Elsevier.

Souza, Jessé de. 2010. Os Batalhadores Brasileiros: Nova Classe Média Ou Nova Classe Trabalhadora? Editora ufmg.

—. 2013. "A Invisibilidade Da Luta de Classes Ou a Cegueira Do Economicismo.” In A "nova Classe Média" no Brasil Como Conceito E Projeto Político, edited by Dawid Danilo Bartelt and Celia Lessa Kerstenetzky, 1a edição, 56-68. Rio de Janeiro: Heinrich Böll Stiftung Brasil. 
Souza, Pedro H. G. Ferreira de. 2012. "Poverty, Inequality and Social Policies in Brazil, 19952009.” 87. Working Paper, International Policy Centre for Inclusive Growth. http://www.econstor.eu/handle/10419/71804.

Telles, Edward E. 2014. Pigmentocracies: Ethnicity, Race, and Color in Latin America. Chapel Hill: UNC Press Books.

Trindade, Luciano Henrique. 2013. Os Sentidos Do Trabalho Para O Jovem Da Nova Classe Média. Ph.D. Dissertation. São Paulo, SP.

Urry, John. 1973. "Towards a Structural Theory of the Middle Class." Acta Sociologica, 175187.

Vicente, Eliana. 2012. “'Nova Classe Média'? Uma Abordagem Antropológica Sobre Consumo, Mobilidade E Inclusão Social.” Universidade Federal Fluminense.

_. 2013. "Nova classe média: Um delírio coletivo?" In A "nova classe média" no Brasil como conceito e projeto político., 1a edição, 84-93. Rio de Janeiro: Heinrich Böll Stiftung Brasil.

Wacquant, Loïc. 1991. "Making Class: The Middle Class(es) in Social Theory and Social Structure.” In Bringing Class Back in: Contemporary and Historical Perspectives, edited by Rhonda F. Levine, 36-64. Boulder: Westview Pr.

Weber, Max. 1978. Economy and Society: An Outline of Interpretive Sociology. Edited by Claus Wittich Guenther Roth. Berkeley: University of California Press.

Weisbrot, Mark, Jake Johnston, and Stephan Lefebvre. 2014. "The Brazilian Economy in Transition: Macroeconomic Policy, Labor and Inequality.” Washington, D.C: Center for Economic and Policy Research. 
World Bank. 2013. "Bolsa Família: Changing the Lives of Millions in Brazil." http://web.worldbank.org/WBSITE/EXTERNAL/NEWS/0,,contentMDK:21447054 pag ePK:64257043 piPK:437376 theSitePK:4607,00.html.

Wright, Erik Olin. 1997. Classes. Verso.

Yaccoub, Hilaine. 2011. “A Chamada' nova Classe Média’: Cultura Material, Inclusão E Distinção Social.” Horizontes Antropológicos 17 (36): 197-231. 